We are grateful to Sir Hector MacLennan and Professor E. M. McGirr for their interest in this work; to the consultant staff of Glasgow Royal Maternity Hospital for their co-operation; to the Medical Research Council and to FBA Pharmaceuticals for financial assistance; and to Mrs. Christine Pidgeon, Mrs. Alison Sandiford, and Mrs. Eileen Cunningham for laboratory assistance.

The work was completed during the tenure by John Bonnar of the Samuel research scholarship of the Royal College of Obstetricians and Gynaecologists.

\section{REFERENCES}

Arthure, H., et al. (1969). Reports on Public Health and Medical Subjects, No. 119, p. 30. London, H.M.S.O.

Biezenski, J. J., and Moore, H. C. (1958) fournal of Clinical Pathology, 11, 306

Biggs, R. (1966). In Treatment of Haemophilia and Other Coagulation Oxford, Blackwell.

Biggs, R. and MacFarlane, R. G. (1962). In Human Blood Coagulation and its Disorders, 3rd ed., p. 384 . Oxford, Blackwell.

Bonnar, J., Davidson J. F., Podgeon, C. F., McNicol, G. P., and Douglas, A. S. (1969a). British Medical fournal, 3, 137.

Bonnar, J., McNicol, G. P., and Douglas, A. S. (1969b). British Medical fournal, 3, 387.

Bonnar, J., McNicol, G. P., and Douglas, A. S. (1970). In press.

Breckenridge, R. T., and Ratnoff, O. D. (1962). Blood, 20, 137.

Dacie, J. V. (1963). Practical Haematology, p. 61. London, Churchill.

Denson, K. W. (1961). Acta Haematologica, 25, 105.

Donald, I. (1969). Practical Obstetric Problems, 4th ed., p. 683. London, Lloyd-Luke Limited.

Douglas, A. S. (1962). Anticoagulant Therapy, p. 279. Oxford, Blackwell.
Husni, E. A., Pena, L. I., and Lenhert, A. E. (1967). American fournal of Obstetrics and Gynecology, 97, 901 .

Kawano, T. Morimoto, K., and Uemura, Y. (1968), Nature, 217, 253. Kawano, T." Morimoto, K., and Uemura, Y. (1968). Nature, 217, 253 of Laboratory and Clinical Medicine, 41, 637 .

McNicol, G. P., Barakat, A. A., and Douglas, A. S. (1965). Scottish Medical fournal, 10, 189.

McNicol, G. P., and Douglas, A. S. (1964). In Recent Advances in Clinical Pathology, Series 4, Edited by S. C. Dyke, p. 187. London, Churchill.

Merskey, C., Kleiner, C. J., and Johnson, A. J. (1966). Blood, 28, 1.

Nilsson, I. M., and Kullander, S. (1967). Acta Obstetrica et Gynecologica Scandinavica, 46, 273.

Nilsson, I. M., and Olow, B. (1962). Acta Chirurgica Scandinavica, 123, 247

Nossel, H. L., Lanzkowsky, P., Levy, S., Mibashan, R. S., and Hansen, J. D. L. (1966). Thrombosis et Diathesis Haemorrhagica, 16, 185.

Owren, P. A., and Aas, K. (1951). Scandinavian fournal of Clinical and Laboratory Investigation, 3, 201

Pechet, L., and Alexander, B. (1961). New England fournal of Medicine 265, 1093.

Proctor, R. R., and Rapaport, S. I. (1961). American fournal of Clinical Pathology, 36, 212.

Ratnoff, O. D., Colopy, J. E., and Pritchard, J. A. (1954). fournal of Laboratory and Clinical Medicine, 44, 408.

Ratnoff, O D., and Menzie, C. (1964). Blood Coagulation, Hemorrhage and Thrombosis, 2nd ed., edited by L. M. Tocantins and L. A. Kazal, P. 224. New York, Grune and Stratton.

Remmert, L. F., and Cohen, P. P. (1949). Fournal of Biological Chemistry, 181, 431.

Shanberge, J. N., Matsuoka, T., and Fukui, H. (1967). American fournal of Clinical Pathology, 47, 533 .

Shaper, A. G., MacIntosh, D. M., and Kyobe, J. (1966). Lancet, 2, 874.

Talbert, L. M., and Langdell, R. D. (1964). American fournal of Obstetrics and Gynecology, 90, 44.

Taylor. E. S. (editor) (1966). In Beck's Obstetrical Practice, 8th ed. p. 188. Baltimore, Williams and Wilkins.

Walker, E. H., and Dormandy, K. M. (1968). Journal of Obstetrics and Gynaecology of the British Commonwealth, 75, 459 .

\title{
Thromboembolic Disease and the Steroidal Content of Oral Contraceptives A Report to the Committee on Safety of Drugs
}

\author{
W. H. W. INMAN,* M.A., M.B., B.CHIR. ; M. P. VESSEY,† M.B., B.S. ; BARBRO WESTERHOLM, $\ddagger$ M.D.
}

\section{A. ENGELUND, $\$ M.P.S.}

Cummary: Reports of thromboembolism following $S$ the use of oral contraceptives received by drug safety committees in the United Kingdom, Sweden, and Denmark have been analysed to investigate possible differences in the risks associated with the various preparations. For this purpose the numbers of reports of thromboembolism attributed to each product were compared with the distribution that would have been expected from market research estimates of sales, assuming that all products carried the same risk.

A positive correlation was found between the dose of oestrogen and the risk of pulmonary embolism, deep vein thrombosis, cerebral thrombosis, and coronary thrombosis in the United Kingdom. A similar association was found for venous thrombosis and pulmonary embolism in Sweden and Denmark. No significant differences could be detected between sequential and combined preparations containing the same doses of oestrogen, nor between the two oestrogens, ethinyloestradiol and mestranol.

Certain discrepancies in the data suggest that the dose of oestrogen may not be the only factor related to the

\footnotetext{
* Senior Medical Officer, Committee on Safety of Drugs, Queen Anne's Mansions, Queen Anne's Gate, London S.W.1.

+ Lecturer in Epidemiology, Department of the Regius Professor of Medicine, The Radcliffe Infirmary, Oxford.

¥ Medical Officer in Charge, Swedish Adverse Drug Reactions Committee, S 104 01, Stockholm 60, Sweden.

5 Pharmaceutical Officer in Charge, Adverse Reactions Board. Danish

National Health Service, Frederikssundsvej 378, DK2700 Brønsh $\phi$, Denmark.
}

risk of thromboembolism; thus there was a significant deficit of reports associated with the combination of mestranol $100 \mu \mathrm{g}$. with norethynodrel $2.5 \mathrm{mg}$. and a significant excess of reports associated with the combination of ethinyloestradiol $50 \mu \mathrm{g}$. with megestrol acetate $4 \mathrm{mg}$. An excess of reports also occurred with other combined preparations containing megestrol acetate.

The data obtained in earlier epidemiological studies were re-examined and, though no trend was obvious in any one of them, the combined results showed an excess of cases of thromboembolism at the highest dose of oestrogen.

The finding of a positive correlation between the dose of oestrogen and the risk of coronary thrombosis is of special interest since previous studies have failed to provide clear evidence of a relationship between oral contraceptives and this condition.

\section{Introduction}

A causal relationship between the use of oral contraceptives and thromboembolic disease was first described in the United Kingdom in a communication to the Medical Research Council in 1967, in which the preliminary results of three studies conducted independently by the Committee on Safety of Drugs, the Medical Research Council's Statistical Research Unit, and the Royal College of General Practitioners were reported. In one of these studies, based on the investigation of deaths due to pulmonary, cerebral, or coron- 
ary thromboembolism, Inman and Vessey (1968) were unable to demonstrate any variation in the risk with different oral contraceptives. Similarly, Vessey and Doll (1969) in their final report on the work of the Medical Research Council's Statistical Research Unit were also unable to demonstrate any difference between the various preparations in women admitted to hospital with non-fatal thromboembolism. More recently, Sartwell et al. (1969), in a retrospective study of women admitted to 48 hospitals in the United States of America, confirmed the relationship between oral contraceptives and thromboembolism, but concluded that the risk was greater among women using sequential products; no comparisons were made between the various combined preparations. In clinical trials involving 797 women Grant (1969) found that leg vein complaints, including thrombophlebitis, occurred most frequently with combined preparations containing a relatively low dose of progestogen and a high dose of oestrogen. No cases of thrombophlebitis occurred in women taking sequential preparations.

Daniel et al. (1967) and several other authors (Jeffcoate et al., 1968; Millar and Robertson, 1968) have shown an increased incidence of puerperal thromboembolism after suppression of lactation with oestrogens, and these substances have also been incriminated as a cause of thromboembolism in controlled clinical trials of their value in coronary artery and cerebrovascular disease (Oliver and Boyd, 1961; Schrogie and Solomon, 1967). An increased risk has also been reported among men treated with oestrogens for prostatic cancer (Bailar, 1967).

Since 1964 the Committee on Safety of Drugs has continuously monitored reports of thromboembolism submitted by doctors and family planning clinics throughout the United Kingdom. In 1966 it was first noticed that there were more reports of thromboembolism following the use of products containing mestranol, and fewer following those containing ethinyloestradiol, than could be accounted for by estimates of sales. More recently, however, it became apparent that the excess of reports was more closely correlated with products containing higher doses of oestrogen than with one or other of the two oestrogens. In this communication we present the results of a detailed analysis of the reports received by the Committee on Safety of Drugs and also of reports to the Swedish Adverse Drug Reaction Committee and the Danish National Health Service's Board on Adverse Reactions to Drugs.

\section{Subjects and Methods}

Between 1 January, 1965 and 30 June, 1969 the Committee on Safety of Drugs received 1,305 reports of thromboembolism occurring in women using oral contraceptives in which the doctors making the reports named the last preparation taken. $\mid$

To determine whether the risk of thromboembolism was related to the dose or nature of the steroids used for contraceptive purposes, it was decided to compare the numbers of reports of thromboembolism attributed to each product with the distribution that would have been expected from market research estimates of sales, assuming that all products carried the same risk. For this purpose estimates of sales by retail pharmacies were provided by Intercontinental Medical Statistics Limited for each of the years 1965-9. Because the

|| During the same period 226 reports of thromboembolism were received in which the oral contraceptive brand name was not specified. In addition, 94 reports of thromboembolism following the use of oestrogen-progestogen mixtures normally prescribed for gynaecological disorders rather than for oral contraception were received, and 45 fatalities from thromboembolism were independently ascertained by the committee during its epidemiological investigation in 1966 (Inman and Vessey, 1968). None of these reports has been included in the present analysis. level of reporting of adverse reactions to the Committee fluctuated from year to year while the overall use of oral contraceptives in the population was increasing steadily, it was necessary to make calculations for each year separately and then to sum the results for the individual years. For example, in 1968 there were 75 reports of non-fatal pulmonary embolism following the use of combined oral contraceptives, of which 26 were associated with the product Ovulen. In that year it was estimated that Ovulen accounted for $22.23 \%$ of the total market. Thus the expected number of reports for Ovulen in 1968 was $\frac{75 \times 22.23}{100}=16.67$

Estimates of oral contraceptive sales by family planning clinics were not available; it was therefore decided to omit 281 reports from this source from the main analysis. Among the 1,024 remaining reports, there were 316 of pulmonary embolism with or without venous thrombosis (67 fatal), 249 of deep venous thrombosis in the lower limb, 266 of venous thrombosis in the lower limb of superficial or unspecified type, 83 of cerebral thrombosis (18 fatal), and 63 of coronary thrombosis ( 25 fatal). To simplify the analysis, a further 37 reports of venous thrombosis affecting parts of the body other than the legs (of which 21 were thrombosis of an arm vein and nine of the portal or hepatic veins), seven reports of retinal artery thrombosis, and three of thrombosis in a limb artery were not included.

In addition to these reports of thromboembolism occurring in the United Kingdom, the Swedish Adverse Drug Reaction Committee and the Danish National Health Service's Board on Adverse Reactions to Drugs supplied details of their experience during the periods January 1965 to December 1968 and May 1968 to September 1969 respectively. Among these data 183 Swedish and 122 Danish reports of pulmonary embolism and venous thrombosis of the lower limb were analysed. As in the United Kingdom, estimates of oral contraceptive sales were used to calculate expected numbers.

It was decided to investigate the following factors which might influence the risk of thromboembolism:

Type of Oral Contraceptive Regimen-that is, Sequential or Combined.-In view of the finding by Sartwell et al. (1969) that sequential oral contraceptives appear to be more likely to cause thromboembolism than combined ones, it was considered that this possibility should be examined first.

Dose and Type of Oestrogen in the Preparation.-Since there is already substantial evidence that oestrogens themselves may cause thromboembolism, the dose of oestrogen was clearly of interest. Additionally, however, it is known that in laboratory animals ethinyloestradiol and mestranol, the two oestrogens used in oral contraceptives, differ in potency by a number of criteria, and it was thought that this might possibly be relevant to the thromboembolic risk.

Dose and Type of Progestogen in the Preparation.-This seemed important because some progestogens have inherent oestrogenic activity or are metabolized to oestrogens, while others have anti-oestrogenic effects.

\section{Type of Regimen}

\section{Results}

In comparing sequential and combined preparations, the reports of venous and arterial thromboembolism in the United Kingdom were considered separately, and the analysis was confined to formulations containing corresponding doses of ethinyloestradiol or mestranol. The comparison (Table I) does not indicate any consistent difference between the ratios of the observed and expected numbers of reports for the two regimens and does not suggest that the sequential preparations are more hazardous than the combined containing the same type and dose of oestrogen. 
TABLE I.-Comparison of Numbers of Reports Observed and Expected in Association with Combined and Sequential Oral Contraceptives (Data for United Kingdom)

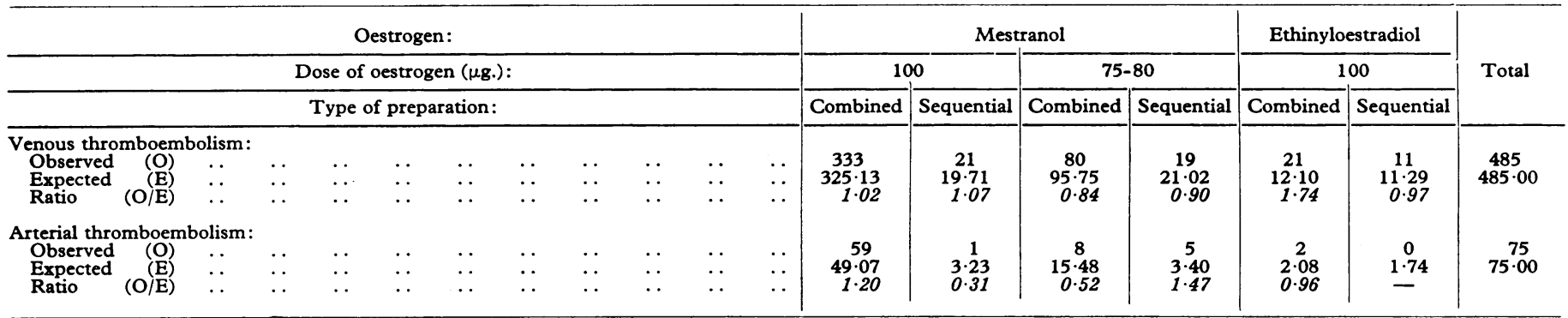

Since, however, there were so few reports associated with sequential oral contraceptives and since women using the sequential method are exposed to the effects of progestogens for only a short time towards the end of each cycle, it was decided to limit the subsequent analyses of the possible effects of oestrogens and progestogens to reports of thromboembolism affecting women using the combined preparations.

\section{Combined Regimen - Influence of Oestrogens}

An analysis of the 920 reports from the United Kingdom relating to combined oral contraceptives, classified according to the type of thromboembolic episode and the dose levels of the two oestrogens contained in the preparations, is shown in Table II. For each diagnostic group there is a consistent excess of reports associated with oral contraceptives containing higher doses of oestrogen, either mestranol or ethinyloestradiol, and a corresponding deficit with those containing lower doses. This trend (interrupted only by a minor discrepancy between the ratios for 75-80 $\mu \mathrm{g}$. and $50 \mu \mathrm{g}$. of mestranol) is particularly noticeable with pulmonary embolism, cerebral thrombosis, and coronary thrombosis and becomes rather less distinct for the less serious types of venous thromboembolism. The results of appropriate tests of statistical significance for the trends are shown in Table III.

It is also possible to make comparisons in Table II be-

TABLE II.-Observed and Expected Numbers of Reports in Relation to Type and Dose of Oestrogen in Combined Oral Contraceptives (Data for United Kingdom)

\begin{tabular}{|c|c|c|c|c|c|c|c|c|c|c|c|c|c|c|c|c|c|}
\hline \multirow{2}{*}{\multicolumn{11}{|c|}{$\begin{array}{c}\text { Oestrogen: } \\
\text { Dose of oestrogen }(\mu \mathrm{g} .):\end{array}$}} & \multicolumn{4}{|c|}{ Mestranol } & \multicolumn{2}{|c|}{ Ethinyloestradiol } & \multirow{2}{*}{ Total } \\
\hline & & & & & & & & & & & \multirow{2}{*}{$\begin{array}{c}150 \\
6 \\
2 \cdot 15 \\
2 \cdot 79\end{array}$} & \multirow{2}{*}{$\begin{array}{c}100 \\
32 \\
20 \cdot 88 \\
1 \cdot 53\end{array}$} & \multirow{2}{*}{$\begin{array}{c}75-80 \\
\begin{array}{c}7 \\
7 \cdot 28 \\
0 \cdot 96\end{array}\end{array}$} & \multirow{2}{*}{$\begin{array}{c}50 \\
1 \\
1.78 \\
0.56\end{array}$} & \multirow{2}{*}{$\begin{array}{c}100 \\
1 \\
1.00 \\
1.00\end{array}$} & \multirow{2}{*}{$\begin{array}{c}50 \\
12 \\
25.91 \\
0.46\end{array}$} & \\
\hline $\begin{array}{l}\text { Fatal pulmonary emb } \\
\text { Observed } \\
\begin{array}{ll}\text { Expected } & (\mathrm{O}) \\
\text { Ratio } & (\mathrm{O} / \mathrm{E}) \\
& \end{array}\end{array}$ & $\begin{array}{l}\text { olis } \\
\cdots \\
\cdots \\
\cdots\end{array}$ & $\begin{array}{l}\ldots \\
\cdots\end{array}$ & $\begin{array}{l}\cdots \\
\cdots\end{array}$ & $\begin{array}{l}\cdots \\
\cdots\end{array}$ & $\begin{array}{l}\cdots \\
\cdots\end{array}$ & $\begin{array}{l}\cdots \\
\cdots\end{array}$ & $\begin{array}{l}\cdots \\
\cdots\end{array}$ & $\begin{array}{l}\cdots \\
\cdots\end{array}$ & $\begin{array}{l}\cdots \\
\cdots\end{array}$ & $\begin{array}{l}\cdots \\
\cdots\end{array}$ & & & & & & & $\begin{array}{c}59 \\
59 \cdot 00\end{array}$ \\
\hline $\begin{array}{l}\text { Non-fatal pulmonary } \\
\text { Observed } \\
\begin{array}{ll}\text { Expected } & (\mathrm{O}) \\
\text { Ratio } & (\mathrm{O} / \mathrm{E}) \\
& \end{array}\end{array}$ & $\begin{array}{l}\text { emt } \\
\cdots \\
\cdots \\
\cdots\end{array}$ & $\begin{array}{l}\text { lism: } \\
\ldots \\
\ldots \\
\ldots\end{array}$ & $\begin{array}{l}\cdots \\
\cdots\end{array}$ & $\begin{array}{l}\ldots \\
\cdots\end{array}$ & $\begin{array}{l}\cdots \\
\cdots\end{array}$ & $\begin{array}{l}\cdots \\
\cdots\end{array}$ & $\begin{array}{l}\cdots \\
\cdots\end{array}$ & $\begin{array}{l}\because \\
\cdots\end{array}$ & $\begin{array}{l}\cdots \\
\cdots\end{array}$ & $\begin{array}{l}\ldots \\
\cdots\end{array}$ & $\begin{array}{l}20 \\
8 \cdot 65 \\
2 \cdot 31\end{array}$ & $\begin{array}{c}100 \\
82 \cdot 68 \\
1 \cdot 21\end{array}$ & $\begin{array}{r}26 \\
28 \cdot 87 \\
0.90\end{array}$ & $\begin{array}{l}7 \\
6 \cdot 83 \\
1 \cdot 02\end{array}$ & $\begin{array}{l}7 \\
3 \cdot 97 \\
1 \cdot 76\end{array}$ & $\begin{array}{r}74 \\
103 \cdot 00 \\
0 \cdot 72\end{array}$ & $\begin{array}{c}234 \\
234 \cdot 00\end{array}$ \\
\hline $\begin{array}{l}\text { Deep vein thrombosis } \\
\text { Observed (O) } \\
\begin{array}{ll}\text { Expected } & \text { (E) } \\
\text { Ratio } & (\mathrm{O} / \mathrm{E})\end{array}\end{array}$ & $\begin{array}{l}\text { s of } \\
\cdots \\
\cdots \\
\cdots\end{array}$ & $\begin{array}{l}\text { wer } 1 \\
\cdots \\
\cdots \\
\cdots\end{array}$ & $\begin{array}{l}\mathrm{b}: \\
\cdots \\
\cdots \\
\cdots\end{array}$ & $\begin{array}{l}. \\
\cdots\end{array}$ & $\begin{array}{l}\cdots \\
\cdots\end{array}$ & $\begin{array}{l}\cdots \\
\cdots\end{array}$ & $\begin{array}{l}\cdots \\
\cdots\end{array}$ & $\begin{array}{l}\cdots \\
\cdots\end{array}$ & $\begin{array}{l}\cdots \\
\cdots\end{array}$ & $\begin{array}{l}\cdots \\
\cdots\end{array}$ & $\begin{array}{l}14 \\
9 \cdot 25 \\
1 \cdot 51\end{array}$ & $\begin{array}{c}98 \\
84 \cdot 41 \\
1 \cdot 16\end{array}$ & $\begin{array}{c}23 \\
26 \cdot 81 \\
0 \cdot 86\end{array}$ & $\begin{array}{l}6 \\
6 \cdot 06 \\
0.99\end{array}$ & $\begin{array}{l}9 \\
3 \cdot 38 \\
2 \cdot 66\end{array}$ & $\begin{array}{c}85 \\
105 \cdot 09 \\
0 \cdot 81\end{array}$ & $\begin{array}{c}235 \\
235 \cdot 00\end{array}$ \\
\hline $\begin{array}{l}\text { Other venous thromb } \\
\text { Observed } \\
\begin{array}{ll}\text { Expected } & (\mathrm{O}) \\
\text { Ratio } & (\mathrm{O} / \mathrm{E}) \\
& \end{array}\end{array}$ & $\begin{array}{l}\text { oosis } \\
\cdots \\
\cdots \\
\cdots\end{array}$ & $\begin{array}{l}\text { low } \\
\cdots \\
\cdots \\
\cdots\end{array}$ & $\begin{array}{l}\operatorname{limb} \\
\ldots \\
\cdots \\
\cdots\end{array}$ & $\begin{array}{l}\cdots \\
\cdots \\
\cdots\end{array}$ & $\begin{array}{l}\cdots \\
\cdots \\
\cdots\end{array}$ & $\begin{array}{l}\cdots \\
\cdots \\
\cdots\end{array}$ & $\begin{array}{l}\cdots \\
\cdots\end{array}$ & $\begin{array}{l}. \\
\cdots \\
.\end{array}$ & $\begin{array}{l}\cdots \\
\cdots \\
\cdots\end{array}$ & $\begin{array}{l}\ldots \\
\cdots \\
\cdots\end{array}$ & $\begin{array}{c}18 \\
11 \cdot 66 \\
1.54\end{array}$ & $\begin{array}{c}103 \\
93.93 \\
1.10\end{array}$ & $\begin{array}{c}24 \\
22.80 \\
1.05\end{array}$ & $\begin{array}{c}8 \\
4 \cdot 75 \\
1 \cdot 68\end{array}$ & $\begin{array}{c}4 \\
2 \cdot 66 \\
1 \cdot 50\end{array}$ & $\begin{array}{c}95 \\
116 \cdot 20 \\
0.82\end{array}$ & $\begin{array}{r}252 \\
252 \cdot 00\end{array}$ \\
\hline $\begin{array}{l}\text { All venous thromboen } \\
\text { Observed } \\
\begin{array}{ll}\text { Expected } & \text { (O) } \\
\text { Ratio } & \text { (O/E) }\end{array} \\
\begin{array}{ll}\text { Ra } & \end{array}\end{array}$ & $\begin{array}{l}\text { mbo } \\
\cdots \\
\cdots \\
\cdots\end{array}$ & $\begin{array}{l}\mathrm{m}: \\
\cdots \\
\cdots\end{array}$ & $\begin{array}{l}\cdots \\
\cdots\end{array}$ & $\begin{array}{l}\cdots \\
\cdots\end{array}$ & $\begin{array}{l}\cdots \\
\cdots\end{array}$ & $\begin{array}{l}. \\
\cdots\end{array}$ & $\begin{array}{l}\cdots \\
\cdots\end{array}$ & $\begin{array}{l}\cdots \\
\cdots \\
\cdots\end{array}$ & $\begin{array}{l}\cdots \\
\cdots\end{array}$ & $\begin{array}{l}\cdots \\
\cdots\end{array}$ & $\begin{array}{c}58 \\
31 \cdot 71 \\
1 \cdot 83\end{array}$ & $\begin{array}{c}333 \\
281 \cdot 90 \\
1 \cdot 18\end{array}$ & $\begin{array}{c}80 \\
85 \cdot 76 \\
0.93\end{array}$ & $\begin{array}{r}22 \\
19 \cdot 42 \\
1 \cdot 13\end{array}$ & $\begin{array}{c}21 \\
11.01 \\
1.91\end{array}$ & $\begin{array}{r}266 \\
350 \cdot 20 \\
0.76\end{array}$ & $\begin{array}{r}780 \\
780 \cdot 00\end{array}$ \\
\hline $\begin{array}{l}\text { Cerebral thrombosis: } \\
\text { Observed } \\
\begin{array}{ll}\text { Expected } & \text { (O) } \\
\text { Ratio } & \text { (O/E) } \\
& \end{array}\end{array}$ & $\begin{array}{l}\ldots \\
\cdots \\
\cdots\end{array}$ & $\begin{array}{l}\cdots \\
\cdots\end{array}$ & $\begin{array}{l}\cdots \\
\cdots\end{array}$ & $\begin{array}{l}. \\
\cdots \\
.\end{array}$ & $\begin{array}{l}\cdots \\
\cdots\end{array}$ & $\begin{array}{l}. \\
\cdots\end{array}$ & $\begin{array}{l}\cdots \\
\cdots \\
\cdots\end{array}$ & $\begin{array}{l}. \\
\cdots\end{array}$ & $\begin{array}{l}\cdots \\
\cdots \\
\cdots\end{array}$ & $\begin{array}{l}\because \\
\cdots \\
.\end{array}$ & $\begin{array}{l}10 \\
3 \cdot 12 \\
3 \cdot 21\end{array}$ & $\begin{array}{c}33 \\
28 \cdot 32 \\
1 \cdot 17\end{array}$ & $\begin{array}{c}6 \\
9 \cdot 10 \\
0.66\end{array}$ & $\begin{array}{c}1 \\
1.98 \\
0.51\end{array}$ & $\begin{array}{c}0 \\
1.09 \\
-\end{array}$ & $\begin{array}{r}29 \\
35 \cdot 39 \\
0.82\end{array}$ & $\begin{array}{c}79 \\
79 \cdot 00\end{array}$ \\
\hline $\begin{array}{l}\text { Coronary thrombosis: } \\
\text { Observed } \\
\begin{array}{ll}\text { Expected } & (\mathrm{O}) \\
\text { Ratio } & (\mathbf{E} / \mathbf{E})\end{array} \\
\begin{array}{ll} & \end{array}\end{array}$ & $\begin{array}{l}: \\
\cdots \\
\cdots\end{array}$ & $\begin{array}{l}\cdots \\
\cdots\end{array}$ & $\begin{array}{l}\cdots \\
\cdots\end{array}$ & $\because$ & $\begin{array}{l}. \\
\cdots\end{array}$ & $\begin{array}{l}. \\
\ldots\end{array}$ & $\begin{array}{l}. \\
\cdots\end{array}$ & $\begin{array}{l}\cdots \\
\cdots\end{array}$ & $\begin{array}{l}. \\
\cdots\end{array}$ & $\begin{array}{l}\cdots \\
\cdots\end{array}$ & $\begin{array}{c}6 \\
2 \cdot 32 \\
2 \cdot 59\end{array}$ & $\begin{array}{r}26 \\
21 \cdot 62 \\
1 \cdot 20\end{array}$ & $\begin{array}{c}2 \\
7 \cdot 12 \\
0 \cdot 28\end{array}$ & $\begin{array}{c}2 \\
1 \cdot 78 \\
1 \cdot 12\end{array}$ & $\begin{array}{c}2 \\
1 \cdot 11 \\
1 \cdot 80\end{array}$ & $\begin{array}{c}23 \\
27.05 \\
0.85\end{array}$ & $\begin{array}{c}61 \\
61 \cdot 00\end{array}$ \\
\hline
\end{tabular}

TABLE III.-Tests of Statistical Significance for Results Shown in Table II

\begin{tabular}{|c|c|c|c|c|c|}
\hline Test & & & Group Tested & $x_{1}^{2}$ & Significance \\
\hline For linear trend in ratio (O/E) with dose of mestranol (See Armitage, 1955) .. & . & .. & $\begin{array}{l}\text { Fatal pulmonary embolism } \\
\text { Non-fatal pulmonary embolism } \\
\text { Deep vein thrombosis of lower limb } \\
\text { Other venous thrombosis of lower limb } \\
\text { All venous thromboembolism } \\
\text { Cerebral thrombosis } \\
\text { Coronary thrombosis }\end{array}$ & $\begin{array}{r}4 \cdot 9 \\
8.9 \\
2 \cdot 6 \\
0.4 \\
12 \cdot 4 \\
12 \cdot 0 \\
6.5\end{array}$ & $\begin{array}{l}\stackrel{+}{\dagger} \\
\text { N.S. } \\
\text { N.S. } \\
\ddagger \\
\ddagger\end{array}$ \\
\hline For difference in ratio between the two doses of ethinyloestradiol & . & . & All groups combined & $14 \cdot 2$ & $\ddagger$ \\
\hline For difference in ratio between $100 \mu \mathrm{g}$. mestranol and $100 \mu \mathrm{g}$. ethinyloestradiol & .. & . & All groups combined & $2 \cdot 7$ & N.S. \\
\hline For difference in ratio between $50 \mu \mathrm{g}$. mestranol and $50 \mu \mathrm{g}$. ethinyloestradiol . & . & .. & All groups combined & $2 \cdot 5$ & N.S. \\
\hline
\end{tabular}

N.S. $P>0.05 . \quad * 0.05>P>0.01 .+0.01>P>0.001 . \neq 0.001>P$. 
tween the two oestrogens, but only at doses of 50 and $100 \mu \mathrm{g}$. It should be noted, however, that only a single product is represented at the $100 \mu \mathrm{g}$. dose of ethinyloestradiol and also at the $50 \mu \mathrm{g}$. dose of mestranol (Nuvacon and Norinyl-1 respectively) and that in both instances the numbers of reports are small (23 and 25 respectively). Within these limitations the results do not suggest a consistent difference between the two oestrogens, since at a dose of $100 \mu \mathrm{g}$., ethinyloestradiol appears to be associated with a greater risk than mestranol, while the reverse is true at a dose of $50 \mu \mathrm{g}$. Furthermore both these differences might reasonably be attributed to chance (Table III).

The distribution of the reports of venous thrombosis and pulmonary embolism from Sweden and Denmark classified by type and dose of oestrogen is shown in Table IV. In these countries it was not possible to compare the two oestrogens at the same dose, but the ratios of observed and expected numbers of reports corresponding to each dose of mestranol follow very much the same trends as those described already for the United Kingdom.

\section{Combined Regimen - Influence of Progestogens}

The data for the United Kingdom, arranged according to the type and dose of both oestrogen and progestogen, are shown in Table V. Fifteen reports related to preparations each of which accounted for less than $1 \%$ of the total market during the period of the study and these have been grouped together under the heading "miscellaneous products"; apart from these, it can be seen that there are 12 combinations of the two oestrogens with one or other of six progestogens, embracing 15 different brands of oral contraceptive.

The progestogenic component of each of these 12 combinations is unique when both type and dose of progestogen are taken into account, and it follows that no comparisons can be made between the oestrogens which are free of the possible influence of the progestogens. On the other hand, comparisons between the progestogens within the same type and dose of oestrogen are possible at the $100 \mu \mathrm{g}$. dose of mestranol and at the $50 \mu \mathrm{g}$. dose of ethinyloestradiol. Both these sets of comparisons suggest that it is not only the oestrogens that are related to the risk of thromboembolism. Thus:

(1) At the $100 \mu \mathrm{g}$. dose of mestranol the combination with 2.5 mg. of norethynodrel (Conovid-E, Previson) shows a significant deficit of reports in every diagnostic group in comparison with the other combinations of progestogen with the same dose of mestranol.

(2) At the $50 \mu \mathrm{g}$. dose of ethinyloestradiol the combination with $4 \mathrm{mg}$. of megestrol (Volidan) shows a significant excess of reports of venous thromboembolism (but not of cerebral or coronary thrombosis) in comparison with other combinations of progestogen with the same dose of ethinyloestradiol.

Certain other discrepancies in the data have already been noted-namely, the excess of reports associated with the 50 $\mu \mathrm{g}$. dose of mestranol in comparison with the 75 or $80 \mu \mathrm{g}$. dose, and the inconsistent findings when comparisons are made between equal doses of the two oestrogens. It is possible that these discrepancies also reflect the influence of the progestogens.

The data from Sweden and Denmark showed no variations which could not be accounted for by the oestrogens. It should be noted, however, that preparations equivalent to those showing major discrepancies in the United Kingdom (Conovid-E, Previson, and Volidan) were either not available in these countries or represented less than $1 \%$ of the total sales. One product available in Sweden and Denmark containing $5 \mathrm{mg}$. of megestrol combined with $100 \mu \mathrm{g}$. of mestranol showed in both countries a small excess of reports when compared with the other products containing the same dose of mestranol. Although this excess was not statistically significant, the finding is of interest in view of the high ratios of observed to expected numbers of reports seen in the United Kingdom with both Nuvacon and Volidan (Table V).

\section{Discussion}

A number of sources of bias might have affected the validity of the results that have been described. Firstly, the use of voluntary reports of adverse reactions for an epidemiological study might be questioned on the grounds that the reports may not truly represent the distribution of the reactions that occur. Secondly, the use of market research data for comparative purposes might be criticized. Thirdly, the choice of brand of oral contraceptive might be influenced by the personal characteristics or the medical history of the individual woman.

\section{Biased Reporting}

Inman and Vessey (1968) showed that, in spite of the publicity attracted by the concern over the safety of oral contraceptives, only $15 \%$ of the deaths from thromboembolic disease that occurred in England, Wales, and Northern Ireland during 1966 among women who were known by their doctors to be using oral contraceptives were reported spontaneously to the Committee on Safety of Drugs. It seems likely that the non-fatal episodes of thromboembolism will have been even less completely reported, and it must, therefore, be recognized that the data available for the present study represent a small fraction, probably less than onetenth, of the events that occurred during the four and a half years in which the reports were collected.

Provided the fraction is representative of the whole, this does not, of course, introduce any bias in itself, but difficulty might arise in the following circumstances: (1) if doctors were particularly likely to report events occurring in association with certain brands of oral contraceptive; (2) if relatively few doctors who favoured certain products were responsible for a substantial proportion of the total number of reports; (3) if there were any important regional variation in the use of different products and in the level of reporting adverse reactions to them; and (4) if general practitioners or hospital doctors reported substantial numbers of cases of thromboembolism occurring in women receiving their supplies of oral contraceptives from family planning clinics, and if the distribution of the products prescribed at such clinics differed from the distribution of those prescribed elsewhere.

Although the first of these possibilities cannot be excluded on the basis of any data available to us, it does not seem likely that bias would arise from this source, except as follows:

Firstly, the Committee on Safety of Drugs requests doctors to report all adverse reactions to new preparations, but only serious or unusual reactions to established ones. The newer products might, therefore, be overrepresented in the reports, especially among those relating to the less serious types of reaction. This, for example, might account for the high ratio of the observed to expected numbers of reports of venous thrombosis of the lower limb for women receiving Norinyl-1 (see Table V). Secondly, there is also the possibility that difficulty might arise from confusing trade names-for example, Conovid, Conovid-E, Lyndiol, Lyndiol 2.5. A separate analysis in which all such products were omitted, however, showed that there was still a pronounced excess of reports associated with combined products containing $100 \mu \mathrm{g}$. of oestrogen (mestranol: observed 278, expected 205; ethinyloestradiol: observed 23, expected 13) and a pronounced deficit of those associated with products containing $50 \mathrm{\mu g}$. of ethinyloestradiol (observed 318, expected 401 ).

The second possibility-variations in prescribing and reporting by different doctors-was considered during the preparation of the reports for analysis. No "clusters" of any appreciable size were found among reports from sources other than family planning clinics.* Among the 258 reports relating to Lyndiol, Conovid-E,

* Reports from family planning clinics are undoubtedly highly "clustered." For example, one group of clinics in Scotland contributed nearly half the reports of adverse reactions to oral contraceptives other than thromboembolism ever received by the Committee on Safety of Drugs. 
TABLE IV.-Reports of Venous Thrombosis and Pulmonary Embolism in Sweden and Denmark

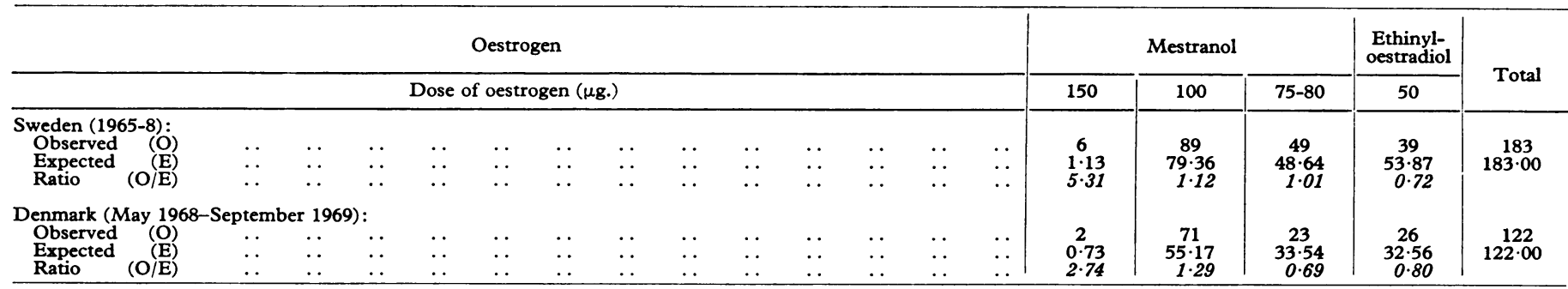

Test for linear trend in ratio $(\mathrm{O} / \mathrm{E})$ with dose of mestranol:

Denmark $X_{1}^{2}=8 \cdot 9,0.01>P>0.001$

TABLE V.-Observed and Expected Numbers of Reports in Relation to Various Combinations of Oestrogens and Progestogens (Data for United Kingdom)

\begin{tabular}{|c|c|c|c|c|c|c|c|c|c|c|c|}
\hline \multicolumn{6}{|c|}{$\begin{array}{c}\text { Oestrogen and Progestogen Content and } \\
\text { Brand Names of Oral Contraceptives }\end{array}$} & & \multirow{2}{*}{$\begin{array}{c}\begin{array}{c}\text { Pulmonary } \\
\text { Embolism }\end{array} \\
\begin{array}{c}26 \\
10.80 \\
2 \cdot 41\end{array}\end{array}$} & \multirow{2}{*}{$\begin{array}{c}\text { Other Venous } \\
\text { Thrombosis } \\
\begin{array}{c}32 \\
20.91 \\
1.53\end{array}\end{array}$} & \multirow{2}{*}{$\begin{array}{c}\begin{array}{c}\text { Cerebral } \\
\text { Thrombosis }\end{array} \\
\begin{array}{c}10 \\
3 \cdot 12 \\
3 \cdot 21\end{array}\end{array}$} & \multirow{2}{*}{$\begin{array}{c}\begin{array}{c}\text { Coronary } \\
\text { Thrombosis }\end{array} \\
\begin{array}{c}6 \\
2.32 \\
2.59\end{array}\end{array}$} & \multirow{2}{*}{$\begin{array}{c}\text { Total } \\
\begin{array}{c}74 \\
37 \cdot 15 \\
1.99\end{array}\end{array}$} \\
\hline $\begin{array}{l}\text { Mestranol } 150 \mu \mathrm{g} . \\
\text { with lynoestrenol } 5 \mathrm{mg} \text {. (Lyndiol) } \quad . .\end{array}$ & .. & .. & . & .. & . & $\underset{\mathrm{O}}{\mathrm{O}}$ & & & & & \\
\hline $\begin{array}{l}\text { Mestranol } 100 \mu \mathrm{g} . \\
\text { with norethynodrel } 2.5 \mathrm{mg} \text {. (Conovid-E, }\end{array}$ & revison & & .. & .. & .. & $\begin{array}{c}\mathrm{O} \\
\mathrm{E} \\
\mathrm{O} / \mathrm{E}\end{array}$ & $\begin{array}{c}17 \\
21 \cdot 80 \\
0 \cdot 78\end{array}$ & $\begin{array}{c}25 \\
43 \cdot 42 \\
0.58\end{array}$ & $\begin{array}{l}1 \\
6 \cdot 05 \\
0 \cdot 17\end{array}$ & $\begin{array}{l}2 \\
4 \cdot 94 \\
0 \cdot 40\end{array}$ & $\begin{array}{c}45 \\
76 \cdot 21 \\
0.59\end{array}$ \\
\hline with norethisterone $2 \mathrm{mg}$. (Ortho-Novin, & Norinyl & & . & .. & . & 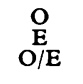 & $\begin{array}{c}19 \\
13.21 \\
1 \cdot 44\end{array}$ & $\begin{array}{c}38 \\
22.36 \\
1 \cdot 70\end{array}$ & $\begin{array}{l}3 \\
3.59 \\
0.84\end{array}$ & $\begin{array}{l}5 \\
2 \cdot 80 \\
1 \cdot 79\end{array}$ & $\begin{array}{r}65 \\
41.96 \\
1.55\end{array}$ \\
\hline with ethynodiol diacetate $1 \mathrm{mg}$. (Ovulen) & .. & .. & $\cdots$ & .. & . & $\underset{\mathrm{O}}{\mathrm{O}}$ & $\begin{array}{c}96 \\
67.85 \\
1 \cdot 41\end{array}$ & $\begin{array}{r}134 \\
111 \cdot 64 \\
1.20\end{array}$ & $\begin{array}{c}29 \\
18.52 \\
1.57\end{array}$ & $\begin{array}{c}19 \\
13.73 \\
1.38\end{array}$ & $\begin{array}{r}278 \\
211.74 \\
1.31 \\
\end{array}$ \\
\hline $\begin{array}{l}\text { Mestranol } 75 \mu \mathrm{g} \text {. } \\
\text { with lynoestrenol } 2.5 \mathrm{mg} \text {. (Lyndiol 2.5) }\end{array}$ & .. & .. & .. & $\cdots$ & . & $\underset{\mathrm{O} / \mathrm{E}}{\mathrm{O}}$ & $\begin{array}{c}26 \\
33.32 \\
0.78\end{array}$ & $\begin{array}{c}43 \\
45 \cdot 15 \\
0.95\end{array}$ & $\begin{array}{l}6 \\
8.44 \\
0.71\end{array}$ & $\begin{array}{c}2 \\
6 \cdot 49 \\
0.31\end{array}$ & $\begin{array}{c}77 \\
93.40 \\
0.82\end{array}$ \\
\hline $\begin{array}{l}\text { Mestranol } 50 \mu \mathrm{g} . \\
\text { with norethisterone } 1 \mathrm{mg} \text {. (Norinyl-1) }\end{array}$ & .. & . & .. & .. & .. & 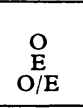 & $\begin{array}{c}8 \\
8.61 \\
0.93 \\
\end{array}$ & $\begin{array}{c}14 \\
10.81 \\
1.30 \\
\end{array}$ & $\begin{array}{l}1.98 \\
1.98 \\
0.51\end{array}$ & $\begin{array}{c}2 \\
1 \cdot 78 \\
1 \cdot 12 \\
\end{array}$ & $\begin{array}{c}25 \\
23 \cdot 18 \\
1 \cdot 08\end{array}$ \\
\hline $\begin{array}{l}\text { Ethinyloestradiol } 100 \mu \mathrm{g} . \\
\text { with megestrol acetate } 2 \mathrm{mg} \text {. (Nuvacon) }\end{array}$ & .. & .. & .. & .. & . & $\underset{\mathrm{O} / \mathrm{E}}{\mathrm{O}}$ & $\begin{array}{l}8 \\
4 \cdot 97 \\
1 \cdot 61\end{array}$ & $\begin{array}{l}13 \\
6.04 \\
2.15\end{array}$ & $\begin{array}{l}0 \\
1.09 \\
-\end{array}$ & $\begin{array}{c}2 \\
1 \cdot 11 \\
1 \cdot 80\end{array}$ & $\begin{array}{c}23 \\
13 \cdot 21 \\
1 \cdot 74\end{array}$ \\
\hline $\begin{array}{l}\text { Ethinyloestradiol } 50 \mu \mathrm{g} . \\
\text { with megestrol acetate } 4 \mathrm{mg} \text {. (Volidan) }\end{array}$ & .. & .. & .. & .. & & $\begin{array}{c}\mathrm{O} \\
\mathrm{E} \\
\mathrm{O} / \mathrm{E}\end{array}$ & $\begin{array}{c}27 \\
22 \cdot 31 \\
1 \cdot 21\end{array}$ & $\begin{array}{c}45 \\
42 \cdot 18 \\
1 \cdot 07\end{array}$ & $\begin{array}{c}2 \\
6 \cdot 33 \\
0.32\end{array}$ & $\begin{array}{c}2 \\
4.85 \\
0.41\end{array}$ & $\begin{array}{c}76 \\
75.67 \\
1.00\end{array}$ \\
\hline with norethisterone acetate $4 \mathrm{mg}$. (Anovla & & . & .. & .. & .. & $\underset{\mathrm{O} / \mathrm{E}}{\mathrm{O}}$ & $\begin{array}{c}12 \\
28.95 \\
0.41\end{array}$ & $\begin{array}{c}38 \\
56 \cdot 20 \\
0.68\end{array}$ & $\begin{array}{l}8 \cdot 6 \\
8 \cdot 14 \\
0.74\end{array}$ & $\begin{array}{l}7 \\
6 \cdot 42 \\
1.09\end{array}$ & $\begin{array}{c}63 \\
99.71 \\
0.63\end{array}$ \\
\hline with norethisterone acetate $3 \mathrm{mg}$. (Gynovl & & .. & .. & .. & . & 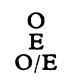 & $\begin{array}{c}35 \\
63.31 \\
0.55\end{array}$ & $\begin{array}{r}83 \\
101 \cdot 37 \\
0.82\end{array}$ & $\begin{array}{c}21 \\
17.32 \\
1 \cdot 21\end{array}$ & $\begin{array}{c}12 \\
12.80 \\
0.94\end{array}$ & $\begin{array}{r}151 \\
194 \cdot 80 \\
0.78\end{array}$ \\
\hline with norethisterone acetate $2.5 \mathrm{mg}$. (Norle & strin) & .. & .. & .. & .. & $\underset{\mathrm{O} / \mathrm{E}}{\mathrm{O}}$ & $\begin{array}{c}5 \\
7.50 \\
0.67\end{array}$ & $\begin{array}{r}7 \\
12 \cdot 60 \\
0.56\end{array}$ & $\begin{array}{c}0 \\
2 \cdot 01 \\
-\end{array}$ & $\begin{array}{c}1 \\
1.52 \\
0.66\end{array}$ & $\begin{array}{c}13 \\
23.63 \\
0.55\end{array}$ \\
\hline with norethisterone acetate $1 \mathrm{mg}$. (Minovl & ar, Orle & & . & .. & .. & $\underset{\mathrm{O}}{\mathrm{O}}$ & $\begin{array}{c}7 \\
6 \cdot 84 \\
1.02\end{array}$ & $\begin{array}{c}7 \\
8.94 \\
0.78\end{array}$ & $\begin{array}{c}0 \\
1 \cdot 59 \\
-\end{array}$ & $\begin{array}{c}1 \\
1.46 \\
0.68\end{array}$ & $\begin{array}{c}15 \\
18.83 \\
0.80\end{array}$ \\
\hline $\begin{array}{l}\text { Miscellaneous Products } \\
\text { (Conovid, Demulen, Ortho-Novin 1/80) }\end{array}$ & .. & .. & .. & .. & . & $\begin{array}{c}\mathrm{O} \\
\mathrm{E} \\
\mathrm{O} / \mathbf{E}\end{array}$ & $\begin{array}{c}7 \\
3.53 \\
1.98 \\
\end{array}$ & $\begin{array}{c}8 \\
5 \cdot 38 \\
1 \cdot 49\end{array}$ & $\begin{array}{l}0 \\
0.82 \\
-\end{array}$ & $\begin{array}{c}0 \\
0.78 \\
-\end{array}$ & $\begin{array}{c}15 \\
10 \cdot 51 \\
1 \cdot 43 \\
\end{array}$ \\
\hline All combined oral contraceptive preparations & & & & & & $\underset{\mathrm{E}}{\mathrm{O}}$ & $\begin{array}{c}293 \\
293 \cdot 00\end{array}$ & $\begin{array}{c}487 \\
487 \cdot 00\end{array}$ & $\begin{array}{c}79 \\
79 \cdot 00\end{array}$ & $\begin{array}{c}61 \\
61 \cdot 00\end{array}$ & $\begin{array}{c}920 \\
920 \cdot 00\end{array}$ \\
\hline
\end{tabular}

Previson, Volidan, and Anovlar, products' which the analysis has shown to be of special interest, there were only five occasions when one doctor had reported two cases of thromboembolism occurring with the same product, and none when more than two were reported.

To investigate the third possibility - that there might have been geographical variation in the level of reporting-the United Kingdom was divided into 10 regions, and the numbers of reports received from these regions were related to the size of the local population. No major disparities were found.

The fourth possibility would be of serious consequence only if family planning clinics prescribed a relatively large proportion of products containing a high dose of oestrogen. This seems unlikely since data on reactions of a minor nature reported by family planning clinics suggest the products containing low doses of oestrogen are prescribed relatively more frequently.

\section{Biased Estimates of Oral Contraceptive Use}

The validity of the data concerning oral contraceptive sales, provided by Intercontinental Medical Statistics Limited, was investigated in two ways. Firstly, comparison was made with estimates supplied in confidence by an independent 
market research organization that uses entirely different methods of data collection. Secondly, the Royal College of General Practitioners provided information about the oral contraceptive preparations used by nearly 19,000 women recruited to a long-term follow-up study (Kay, 1970, personal communication). There was remarkably good agreement between these two sets of data and those provided by Intercontinental Medical Statistics Limited.

It may also be noted that in an attempt to find some "internal" control data, about 800 reports of reactions other than thrombosis were examined with a view to identifying a group or groups of reports of reactions which could reasonably be considered to be unrelated to oral contraceptives-for example, cancer of the breast or cervix developing within a short time of the start of the medication. Most of the conditions described in the reports, however, were either recognized side-effects of oral contraceptives or conditions which might well be produced by them. Only jaundice, skin reactions, hypertension, headache, and depression were mentioned on 40 or more occasions. Each of these groups of reports was analysed in the same way as the data for thromboembolism and no well-defined trends with dose of oestrogen were apparent.

\section{Other Biases}

Age.-If preparations containing high doses of oestrogen were used particularly by older women, than an excess of adverse reactions might be attributed to such products merely as a result of the increasing incidence of thromboembolic disease with age. The ages of the women with thromboembolism were, therefore, examined in relation to the oral contraceptive preparations specified in the reports. No appreciable differences were found. Data collected at the beginning of the long-term follow-up study being conducted by the Royal College of General Practitioners also indicate that there is no difference in the choice of product for women of different ages (Kay, 1970, personal communication).

Indication for Use of Oral Contraceptives.-The standard "yellow card" used by doctors to report adverse reactions to the Committee on Safety of Drugs does not include specific questions about the indications for treatment, though such information is often volunteered. It follows that a proportion of the reports included in the analysis relate to women who were using oral contraceptives for reasons other than conception control. It could be argued that such women might have medical conditions predisposing to thromboembolism, and that if products containing high doses of oestrogen were particularly likely to be prescribed for them, a serious bias might result. For example, such a bias might have affected the reports associated with one of the products of major significance in the present study, Lyndiol, since active promotion of this preparation as an oral contraceptive ceased at the end of 1965 in favour of Lyndiol 2.5. It should be noted, however, that Lyndiol is still listed as an oral contraceptive in the Monthly Index of Medical Specialities (MIMS) which is widely used for prescribing by practising physicians. Furthermore, of the 74 reports of thromboembolism following the use of Lyndiol, 40 related to patients who had started treatment before the promotion of the product as an oral contraceptive ceased. Of the remainder, the reason for use of the product was indicated in 21 reports, and 17 patients were definitely using Lyndiol for conception control. It seems very unlikely, therefore, that the data for Lyndiol are seriously biased.

As a result of all these considerations, it is concluded that there are no detectable sources of bias in the present data which could have been responsible for the association between the oestrogen content of oral contraceptives and the risk of thromboembolism.

\section{Comparison with other Studies}

Data concerning the types of oral contraceptive associated with thromboembolism have been collected in three previous epidemiological investigations, and the results have been outlined in the introduction to the present report.

An analysis of the data for combined oral contraceptives in these three investigations is shown in Table VI. The numbers involved in each study are small and no consistent trend in the ratios of observed to expected numbers can be seen in any one of them. When the data for the three studies are combined, however, an excess of cases associated with oral contraceptives containing $150 \mu \mathrm{g}$. of oestrogen emerges.

\section{Significance of Present Results}

We conclude that the data collected independently in the three countries leave no doubt that there is a positive correlation between the risk of thromboembolism and the dose of oestrogen in oral contraceptives. We have been unable to demonstrate a difference between the two oestrogens, ethinyloestradiol and mestranol, but this comparison is based on very small numbers of reports. No evidence has been obtained that the risks associated with combined and sequential oral contraceptives are different when comparisons are made between preparations containing the same type and dose of oestrogen.

While our present findings suggest that the oestrogenic content of oral contraceptives is likely to be the most important factor determining the risk of thromboembolism, certain discrepant results obtained with Conovid-E and Previson on the one hand, and Volidan on the other, suggest that other factors are also involved, of which the most likely is some influence of the progestogens. Conovid-E and Previson appear to be associated with an unexpectedly low risk of thromboembolism, and this is particularly hard to explain because norethynodrel, the progestogen in these preparations, is a 19-nor-steroid which, in animals at least, has an oestrogenic effect (Drill, 1966). Volidan on the other hand, which

TABLE VI.-Findings in Other Investigations*

\begin{tabular}{|c|c|c|c|c|c|c|c|c|c|c|c|c|c|c|c|}
\hline \multirow{2}{*}{\multicolumn{4}{|c|}{ Dose of Oestrogen $(\mu \mathrm{g})}}$. & \multicolumn{3}{|c|}{ Inman and Vessey $(1968) \dagger$} & \multicolumn{3}{|c|}{ Vessey and Doll (1969)† } & \multicolumn{3}{|c|}{ Sartwell et al. (1969) $\ddagger$} & \multicolumn{3}{|c|}{ All Three Studies } \\
\hline & & & & \multirow{2}{*}{$\begin{array}{c}\text { Observed } \\
4 \\
15 \\
1 \\
14\end{array}$} & \multirow{2}{*}{$\begin{array}{c}\text { Expected } \\
1.90 \\
13.00 \\
2.29 \\
16.81\end{array}$} & \multirow{2}{*}{$\begin{array}{c}\text { Ratio } \\
2 \cdot 11 \\
1.15 \\
0.44 \\
0.83\end{array}$} & \multirow{2}{*}{$\begin{array}{c}\text { Observed } \\
6 \\
16 \\
2 \\
27\end{array}$} & \multirow{2}{*}{$\begin{array}{c}\text { Expected } \\
2.56 \\
20.54 \\
3.43 \\
24.47\end{array}$} & \multirow{2}{*}{$\begin{array}{l}\text { Ratio } \\
2.34 \\
0.78 \\
0.58 \\
1.10\end{array}$} & \multirow{2}{*}{$\begin{array}{c}\text { Observed } \\
2 \\
32 \\
5 \\
9\end{array}$} & \multirow{2}{*}{$\begin{array}{c}\text { Expected } \\
2 \cdot 09 \\
27 \cdot 13 \\
4 \cdot 17 \\
14 \cdot 61\end{array}$} & \multirow{2}{*}{$\begin{array}{l}\text { Ratio } \\
0.96 \\
1.18 \\
1.20 \\
0.62\end{array}$} & \multirow{2}{*}{$\begin{array}{c}\text { Observed } \\
12 \\
63 \\
8 \\
50\end{array}$} & \multirow{2}{*}{$\begin{array}{c}\text { Expected } \\
6.55 \\
60.67 \\
9.89 \\
55.89\end{array}$} & \multirow{2}{*}{$\begin{array}{l}\text { Ratio } \\
1.83 \\
1.04 \\
0.81 \\
0.89\end{array}$} \\
\hline $\begin{array}{l}150 \\
100 \\
75-80 \\
50-60\end{array}$ & $\begin{array}{l}\because \\
\because \\
\therefore\end{array}$ & $\begin{array}{l}. \\
\therefore \\
\therefore\end{array}$ & $\begin{array}{l}\because \\
\because \\
\because\end{array}$ & & & & & & & & & & & & \\
\hline \multicolumn{4}{|c|}{ Total } & 34 & $34 \cdot 00$ & & 51 & $51 \cdot 00$ & & 48 & $48 \cdot 00$ & & 133 & $133 \cdot 00$ & \\
\hline
\end{tabular}

* All the data relate to women using oral contraceptives who had no known conditions predisposing to thromboembolism.

†Data for venous thrombosis, pulmonary embolism, intracranial vascular lesions, and retinal vascular lesions. Expected numbers calculated from study control data. 
TABLE VII.-Relative Risks of Thromboembolism at Various Dose-levels of Oestrogen (Data for United Kingdom). Values Based on an Expected Number of Less than 10 Reports are Shown in Italics

\begin{tabular}{|c|c|c|c|c|c|c|c|c|c|c|c|c|c|c|c|c|}
\hline \multicolumn{10}{|c|}{ Oestrogen } & \multicolumn{4}{|c|}{ Mestranol } & \multicolumn{2}{|c|}{ Ethinyloestradiol } & \multirow{2}{*}{$\begin{array}{l}\text { No. of } \\
\text { Reports }\end{array}$} \\
\hline \multicolumn{10}{|c|}{ Dose ( $\mu \mathrm{g})}$. & 150 & 100 & $75-80$ & 50 & 100 & 50 & \\
\hline $\begin{array}{l}\text { Fatal pulmonary emboli } \\
\text { Non-fatal pulmonary en } \\
\text { Deep venous thrombosi } \\
\text { Other venous thrombosi }\end{array}$ & $\begin{array}{l}\text { sm } \\
\text { low } \\
\text { low }\end{array}$ & $\begin{array}{c}\cdots \\
\dot{i m b} \\
\operatorname{limb}\end{array}$ & $\begin{array}{l}\cdots \\
\cdots \\
\cdots\end{array}$ & $\begin{array}{l}\cdots \\
\cdots \\
\cdots\end{array}$ & $\begin{array}{l}\ldots \\
\cdots \\
\cdots\end{array}$ & $\begin{array}{l}\cdots \\
\cdots \\
\cdots\end{array}$ & $\begin{array}{l}\ldots \\
\cdots \\
\cdots\end{array}$ & $\begin{array}{l}\ldots \\
\cdots \\
\cdots\end{array}$ & $\begin{array}{l}\ldots \\
\cdots \\
\cdots\end{array}$ & $\begin{array}{l}6 \cdot 0 \\
3 \cdot 2 \\
1 \cdot 9 \\
1 \cdot 9\end{array}$ & $\begin{array}{l}3 \cdot 3 \\
1 \cdot 7 \\
1 \cdot 4 \\
1 \cdot 3\end{array}$ & $\begin{array}{l}2 \cdot 1 \\
1 \cdot 3 \\
1 \cdot 1 \\
1 \cdot 3\end{array}$ & $\begin{array}{l}1 \cdot 2 \\
1 \cdot 4 \\
1 \cdot 2 \\
2 \cdot 1\end{array}$ & $\begin{array}{l}2 \cdot 2 \\
2 \cdot 5 \\
3 \cdot 3 \\
1 \cdot 8\end{array}$ & $\begin{array}{l}1 \cdot 0 \\
1.0 \\
1 \cdot 0 \\
1 \cdot 0\end{array}$ & $\begin{array}{r}59 \\
234 \\
235 \\
252\end{array}$ \\
\hline All venous thrombosis & .. & $\ldots$ & $\ldots$ & . & . & . & .. & . & . & $2 \cdot 4$ & $1 \cdot 6$ & $1 \cdot 2$ & $1 \cdot 5$ & $2 \cdot 5$ & $1 \cdot 0$ & 780 \\
\hline Cerebral thrombosis .. & . & $\cdots$ & $\ldots$ & $\ldots$ & $\ldots$ & . & $\ldots$ & . & $\ldots$ & $3 \cdot 9$ & $1 \cdot 4$ & 0.8 & 0.6 & - & $1 \cdot 0$ & 79 \\
\hline Coronary thrombosis & .. & $\ldots$ & $\ldots$ & $\ldots$ & $\ldots$ & $\ldots$ & $\ldots$ & $\ldots$ & $\ldots$ & $3 \cdot 0$ & $1 \cdot 4$ & 0.3 & $1 \cdot 3$ & $2 \cdot 1$ & $1 \cdot 0$ & 61 \\
\hline
\end{tabular}

TABLE VIII.-Comparison of Relative Risks of Venous Thromboembolism in the United Kingdom, Sweden and Denmark. Values Based on an Expected Number of Less than 10 reports are Shown in Italics

\begin{tabular}{|c|c|c|c|c|c|c|c|c|c|c|c|c|c|c|c|c|c|c|c|}
\hline \multicolumn{15}{|c|}{ Oestrogen } & \multicolumn{3}{|c|}{ Mestranol } & Ethinyl- & \multirow{2}{*}{$\begin{array}{l}\text { No. of } \\
\text { Reports }\end{array}$} \\
\hline \multicolumn{15}{|c|}{ Dose ( $\mu \mathrm{g})}$. & 150 & 100 & $75-80$ & 50 & \\
\hline $\begin{array}{l}\text { United Kingdom } \\
\text { Sweden } \quad \cdots \\
\text { Denmark }\end{array}$ & $\begin{array}{l}\ldots \\
\cdots\end{array}$ & $\begin{array}{l}\ldots \\
\cdots \\
\cdots\end{array}$ & $\begin{array}{l}\cdots \\
\cdots \\
\cdots\end{array}$ & $\begin{array}{l}\ldots \\
\cdots \\
\cdots\end{array}$ & $\begin{array}{l}\ldots \\
\cdots\end{array}$ & $\begin{array}{l}\cdots \\
\cdots\end{array}$ & $\begin{array}{l}. \\
\because \\
.\end{array}$ & $\begin{array}{l}\ldots \\
\cdots \\
.\end{array}$ & $\begin{array}{l}\cdots \\
\cdots \\
\cdots\end{array}$ & $\begin{array}{l}\cdots \\
\cdots \\
\cdots\end{array}$ & $\begin{array}{l}\ldots \\
\cdots \\
\cdots\end{array}$ & $\begin{array}{l}\ldots \\
\ldots \\
\ldots\end{array}$ & $\begin{array}{l}\cdots \\
\cdots \\
\cdots\end{array}$ & $\begin{array}{l}\ldots \\
\cdots \\
\cdots\end{array}$ & $\begin{array}{l}2 \cdot 4 \\
7 \cdot 3 \\
3 \cdot 4 \\
\end{array}$ & $\begin{array}{l}1.6 \\
1.6 \\
1.6 \\
\end{array}$ & $\begin{array}{l}1 \cdot 2 \\
1.4 \\
0.9\end{array}$ & $\begin{array}{l}1 \cdot 0 \\
1.0 \\
1.0\end{array}$ & $\begin{array}{l}780 \\
183 \\
122\end{array}$ \\
\hline
\end{tabular}

appears to be associated with an unexpectedly high risk, contains megestrol acetate, a 17 $\alpha$-hydroxy-progesterone derivative without any oestrogenic activity. It has also been noted that the two other products containing megestrol (one available in the United Kingdom and one in Scandinavia) show a high ratio of observed to expected numbers of reports. Other variables, such as the degree of absorption of the different preparations from the alimentary tract, might be relevant to these results while the possibility also remains that they are artifacts produced by some undetected bias in our figures.

No conclusive evidence has been obtained in any of the controlled epidemiological studies that oral contraceptives cause coronary thrombosis, though Inman and Vessey (1968) found a significant association in women who developed the disease in the absence of predisposing conditions and who were not obese. It is therefore of considerable interest that similar trends have been found for coronary thrombosis in the present investigation as for pulmonary embolism and cerebral thrombosis. There are a number of possible explanations for this result. Firstly, it might be attributed to chance, though tests of statistical significance (Table III) suggest that this is not very likely. Secondly, it is possible that a proportion of the patients who were said to have had coronary thrombosis, in fact suffered pulmonary embolism, though $70 \%$ of the diagnoses had been confirmed electrocardiographically or by post-mortem examination and most of the remainder were reported by hospital doctors. Thirdly, a real association between the use of oral contraceptives and coronary thrombosis might have been missed in the earlier studies. Whatever the explanation, the need for further investigation is clear.

Since adverse reactions are incompletely reported, it is not possible from these data to determine the risk of thromboembolism in absolute terms. In Table VII, however, the relative risks in the United Kingdom have been estimated for each diagnostic group, taking the risk with products containing $50 \mu \mathrm{g}$. of ethinyloestradiol as unity. A similar comparison is shown in Table VIII between the risks for all forms of venous thromboembolism in the three countries.

Voluntary reports of adverse reactions to drugs have often alerted the Committee on Safety of Drugs to potential drug- safety problems, but only among reports of adverse reactions to oral contraceptives have sufficient data so far accumulated to enable the present type of analysis to be made.

The data are admittedly imperfect, but it has been possible to reach firm conclusions concerning the risk of thromboembolism associated with certain oral contraceptive preparations. We believe that the results of this study illustrate the great value of national monitoring systems and of close liaison between countries operating them.

We wish to express our gratitude to Sir Austin Bradford Hill, Professor Richard Doll, Professor David Finney, and Mr. Richard Peto for their help in the preparation of the paper and the statistical interpretation of the results; to Professor Eric Scowen and Professor Owen Wade and the members of the Committee on Safety of Drugs and its Adverse Reactions Sub-Committee; to Professor Ake Liljestrand and the members of the Swedish Adverse Drug Reaction Committee; to Chief Physician Asger Pedersen and the Danish Health Services Board on Adverse Reactions for their advice and help; to Intercontinental Medical Statistics Limited for estimates of oral contraceptive use in the United Kingdom; and to Dr. Clifford Kay and the Royal College of General Practitioners for comparative data on oral contraceptive use and the age distribution of patients.

Request for reprints should be addressed to Dr. W. H. W. Inman.

\section{REFERENCES}

Armitage, P. (1955). Biometrics, 11, 375.

Bailar, J. C. (1967). Lancet, 2, 560

Daniel, D. G., Campbell, H., and Turnbull, A. C. (1967). Lancet, 2, 287.

Drill, V. A. (1966). Oral Contraceptives. McGraw-Hill, New York.

Grant, E. C. G. (1969). British Medical fournal, 4, 73.

Inman, W. H. W., and Vessey, M. P. (1968). British Medical Journal,

2, 193.
Jeffcoate, T. N. A., Miller, J., Roos, R. F., and Tindall, V. R. (1968). British Medical fournal, 4, 19.

Medical Research Council (1967). British Medical fournal, 2, 355.

Millar, D. G., and Robertson, E. G. (1968). British Medical fournal, 4, 452 .

Oliver, M. F., and Boyd, G. S. (1961). Lancet, 2, 499.

Sartwell, P. E., Masi, A. T., Arthes, F. G., Greene, G. R., and Smith H. E. (1969). American łournal of Epidemiology, 90, 365.

Schrogie, J. J)., and Solomon, H. M. (1967). 'foumal of Chronic Diseases, $20,675$.

Vessey, M. P., and Doll, R. (1969). British Medical fournal, 2, 651. 